Regiony, metropolie, miasta

ISSN 1899-3192

e-ISSN 2392-0041

\author{
Monika Musial-Malago' \\ Państwowa Wyższa Szkoła Zawodowa w Nowym Sączu \\ Uniwersytet Ekonomiczny w Krakowie \\ e-mail: musialm@uek.krakow.pl
}

\title{
PRZESTRZENNE ZRÓŻNICOWANIE PROCESU KURCZENIA SIE MIAST W POLSCE SPATIAL DIVERSITY OF THE PROCESS OF URBAN SHRINKAGE IN POLAND
}

DOI: $10.15611 /$ pn.2017.467.06

JEL Classification: P25, R23

Streszczenie: Kurczenie się miast stanowi obecnie aktualny problem procesów urbanizacyjnych w Polsce. Zmiany ustrojowe w Polsce i proces integracji z Unią Europejską wpłynęły na strukturę i dynamikę zachodzących zmian w populacji kraju, w tym szczególnie na obszary miejskie. Przedmiotem opracowania jest identyfikacja głównych przejawów kurczenia się miast na tle zjawisk ludnościowych. Autorka scharakteryzowała aktualną sytuację w miastach wojewódzkich w Polsce w kontekście depopulacji. Zakres czasowy analizy obejmuje lata 2000-2015.

Słowa kluczowe: kurczenie się miast, proces depopulacji, miasta polskie.

Summary: Urban shrinkage is currently a problem of urbanisation processes in Poland. Systemic changes in Poland, and subsequently the process of integration with the European Union affected the structure and dynamics of the changes in the population of the country, especially in urban areas. The main issue of this paper is to identify the main symptoms of urban shrinking within the area of population changes. The author has characterised the current situation in Polish cities in the context of depopulation phenomena. The analysed period covers the years 2000-2015.

Keywords: shrinking of cities, depopulation process, Polish cities.

\section{Wstęp}

Kurczenie się miast stanowi obecnie jeden z ważniejszych problemów współczesnego rozwoju miast w całej Europie, w tym również w Polsce. Zmiany ustrojowe i proces integracji z Unią Europejską wpłynęły na strukturę i dynamikę zmian w populacji kraju, w tym szczególnie w miastach. 
Celem artykułu jest przedstawienie problematyki „kurczących się” miast w obszarze zjawisk depopulacji. Zakres przestrzenny analizy obejmuje miasta wojewódzkie. W niniejszym opracowaniu dokonano ogólnej charakterystyki tego procesu, uwzględniając jedynie zmiany zaludnienia. Jest to jeden z ważniejszych wskaźników, na podstawie którego można dokonać identyfikacji skali tego zjawiska. Zakres czasowy analizy obejmuje lata 2000-2015. Okres ten wydaje się dostatecznie długi, aby można było pokazać obraz przemian ludnościowych, jakie wówczas zaszły w miastach.

\section{Istota, przyczyny i skutki kurczenia się miast}

Kurczenie się miast jest jednym z ważniejszych zjawisk społecznych, gospodarczych oraz przestrzennych, które zachodzą we współczesnej miejskiej sieci osadniczej. Obecnie wiele miast traci mieszkańców i w przyszłości zjawisko to będzie się nasilać. Nie oznacza to jednak, że proces kurczenia się miast dotyka wszystkie ośrodki miejskie.

Termin „kurczenie się miasta” jest pojęciem wieloaspektowym, złożonym i zróżnicowanym, różne są bowiem jego przyczyny i skutki. Kurczenie się miast $\mathrm{w}$ literaturze przedmiotu opisywane jest jako proces zmniejszania się liczby jego mieszkańców, przy czym należy zaznaczyć, że różne są trajektorie depopulacji, różne czynniki kształtujące to zjawisko oraz różne jego konsekwencje [Kantor-Pietraga, Krzysztofik, Runge 2012, s. 17].

Zagadnieniu „kurczenia się” miast poświęcono wiele prac w Europie [Bernt i in. 2012; Couch i in. 2012; Rink i in. 2012; Haase i in. 2013], w tym szczególnie w Niemczech. W Polsce wyzwania demograficzne i związany z nim proces kurczenia się miast dostrzegane są w Koncepcji Przestrzennego Zagospodarowania Kraju 2030, Krajowej Strategii Rozwoju Regionalnego 2010-2020 oraz Krajowej Polityce Miejskiej 2023. Należy jednak zaznaczyć, że badania naukowe nad implikacjami zjawiska shrinking cities w Polsce nie są wciąż powszechnie prowadzone.

Zgodnie z definicją przyjętą przez Shrinking Cities International Research Network (SCIRN) miastem kurczącym się jest obszar miejski charakteryzujący się dużą gęstością zaludnienia, liczący powyżej 10 tys. mieszkańców, w którym odnotowuje się spadek liczby ludności trwający powyżej 5 lat, o nasileniu wyższym niż $0,15 \%$ rocznie. Kurczące się miasto to również taki obszar miejski, który został dotknięty kryzysem strukturalnym w wyniku zachodzącego procesu transformacji gospodarczej [Stryjakiewicz 2014, s. 11-12].

Podstawowym wskaźnikiem w badaniach nad procesem kurczenia się miast jest spadek liczby jego mieszkańców. Może on następować na skutek takich czynników, jak: migracje i ujemny przyrost naturalny. Wraz ze spadkiem liczby mieszkańców miasta pojawiają się różnego rodzaju problemy o charakterze społecznym, gospodarczym i przestrzennym pozostające z nim w związku przyczynowo-skutkowym. Spadek liczby mieszkańców miasta nie zawsze jednak świadczy o wielowymiaro- 
wości tego procesu [Stryjakiewicz 2014, s. 93]. Ponadto nie wszystkie miasta, w których zachodzi proces depopulacji, należy uznać za kurczące się. Dotyczy to zwłaszcza dużych miast, które podlegają silnym procesom suburbanizacji.

Przyczyn kurczenia się miast jest wiele i są one różnorakie. Ważną kwestią jest kryzys ich lokalnej gospodarki [Haase 2013, s. 32]. Otwarcie Polski na procesy globalne ujawniło zacofanie gospodarcze w wielu miastach, wskutek czego konieczna stała się restrukturyzacja ich gospodarek. Upadek tradycyjnych gałęzi i branż gospodarki oraz likwidacja zakładów przemysłowych wpłynęły na zmianę funkcji ekonomicznej miast oraz zmianę dotychczasowych struktur przestrzennych, społecznych i demograficznych. Dostosowanie do nowych warunków rynkowych było szczególnie trudne w miastach, które nie miały zróżnicowanych funkcji, a dominującą gałęzią ich gospodarki był przemysł. Miasta, które nie zdołały rozwinąć nowoczesnego przemysłu lub przekształcić się w nowoczesne ośrodki usługowe w czasie przemian, obecnie przeżywają kryzys. Skutkiem tych zmian jest zła sytuacja na ich rynku pracy. Nastąpił gwałtowny wzrost bezrobocia i związane z nim ubóstwo, segregacja i marginalizacja społeczna [Musiał-Malago' 2015, s. 117-118, 147-148]. Doprowadziło to do depopulacji tych miast wskutek masowych migracji mieszkańców do ośrodków miejskich oferujących zatrudnienie i lepsze warunki życia [Stryjakiewicz 2014, s. 80].

Zjawisko kurczenia się miast można ujmować w dwóch wymiarach - jako kurczenie się rzeczywiste i pozorne. W pierwszym aspekcie zjawisko to oznacza, iż depopulacji $\mathrm{w}$ danym czasie podlega miasto wraz $\mathrm{z}$ otoczeniem, drugi wymiar dotyczy sytuacji, kiedy to ubytek ludności w danym mieście kompensowany jest wzrostem liczby ludności w jego otoczeniu suburbialnym [Kantor-Pietraga 2014, s. 163-164].

Kurczenie się miasta ma wpływ na wiele jego obszarów. Ubytek populacji miejskiej jest zarówno efektem, jak i przyczyną dalszego pogłębiania się procesu kurczenia się miast. Można zatem w tym wypadku nawiązać do teorii kumulatywnej przyczynowości Myrdala z 1956 roku. Przedstawiony przez autora mechanizm kurczenia się, tzw. model błędnego koła kurczenia się, wykazuje tendencje kumulatywne i prowadzi do nasilania się negatywnych konsekwencji tego procesu (rys. 1) [Jaroszewska 2013, s. 59].

Demograficzne konsekwencje procesu kurczenia się miast wyrażają się spadkiem liczby mieszkańców miasta. Z kolei ubytek ludności miejskiej wpływa niekorzystnie na procesy ekonomiczne. W efekcie następuje spowolnienie rozwoju lub regres rynku konsumpcyjnego, ograniczenie wymiaru rynku pracy czy spadek liczby podmiotów gospodarczych. $Z$ powodu depopulacji spada popyt na nowe mieszania i obniża się zapotrzebowanie na lokale na rynku wtórnym. Proces kurczenia się miasta wpływa negatywnie na stan finansów samorządów miejskich. Sytuacja dochodowa miast o charakterze wyludniającym się ulega pogorszeniu. Znajduje to odzwierciedlenie m.in. w spadku dochodów własnych miast generowanych odpływem mieszkańców i likwidacją podatków od prowadzonej działalności gospodarczej (CIT, PIT, podatki lokalne) [Musiał-Malago' 2015, s. 139-140]. 


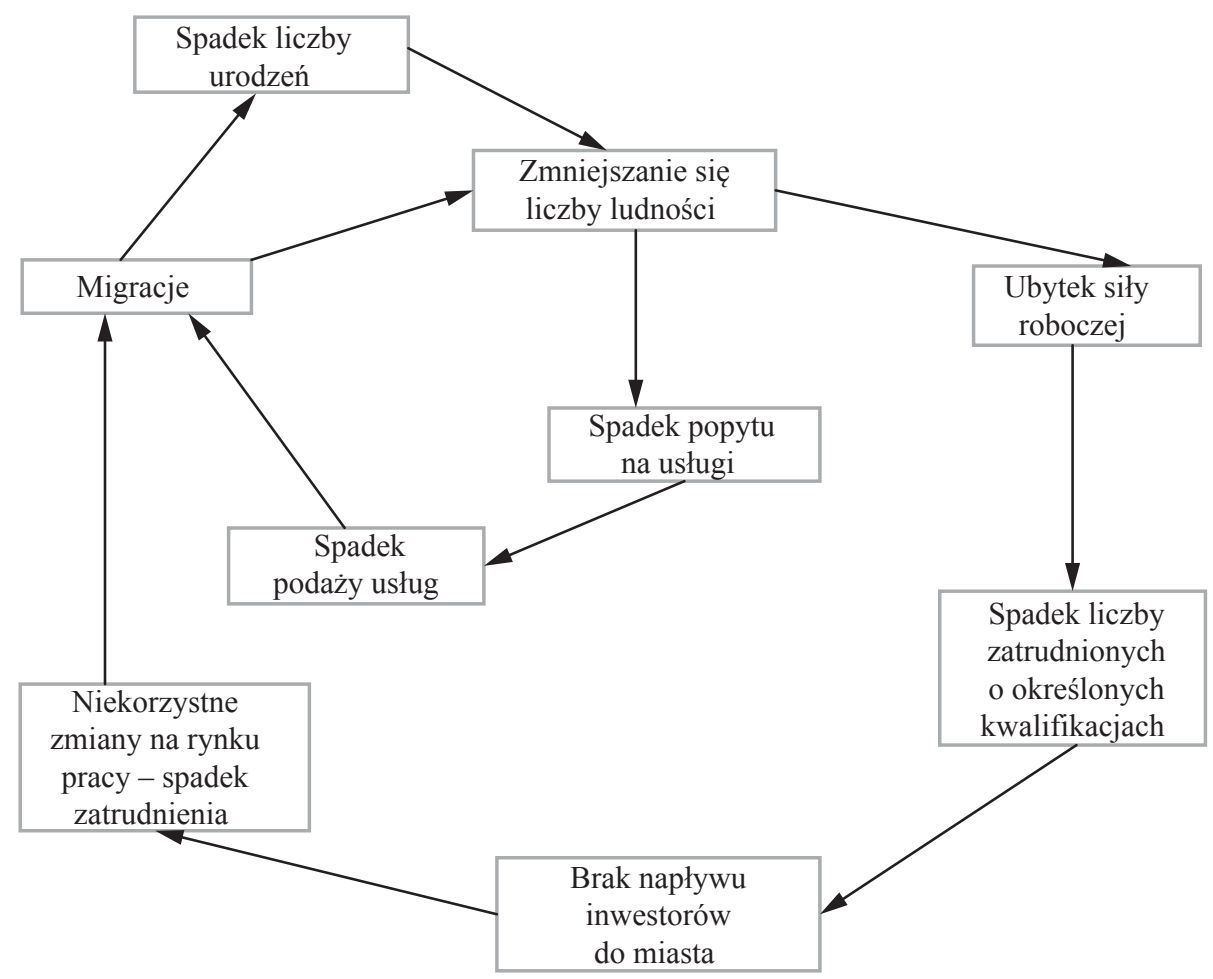

Rys. 1. Proces kurczenia się miast według teorii kumulatywnej przyczynowości Myrdala Źródło: [Stryjakiewicz 2014, s. 14; Jaroszewska 2013, s. 59].

Skutki kurczenia się miast uwidaczniają się również w strukturze wieku ludności. Następuje spadek liczby dzieci i młodzieży w wieku do 17 lat oraz stały wzrost liczby osób w wieku emerytalnym. Efektem tych zmian jest wzrost obciążenia demograficznego, ubożenie społeczeństwa, nadmierne obciążenie systemu emerytalnego. Rosnąca liczba ludzi starych zwiększa również zapotrzebowanie na usługi medyczne i pomoc społeczną, co ma bezpośredni wpływ na wzrost wydatków jednostek samorządu terytorialnego. Procesy depopulacji prowadzą ponadto do zmniejszania się gęstości zaludnienia, co powoduje wzrost jednostkowych kosztów funkcjonowania miast, w tym szczególnie utrzymania i rozwoju infrastruktury oraz obniżenia wskaźników jej wykorzystania. Do negatywnych skutków depopulacji można zaliczyć osłabienie podstaw funkcjonowania usług komercyjnych czy obiektów publicznych [Czarnecki 2011, s. 14-17].

Spadek liczby mieszkańców na obszarach centralnych miast prowadzi do zmian w przestrzeni miejskiej. Wzrasta liczba pustostanów, terenów i obiektów nieużywanych, następuje spadek wartości nieruchomości oraz osłabienie zainteresowania lokowaniem nowych inwestycji, co w konsekwencji prowadzi do perforacji struktur 
przestrzennych, a także ich kurczenia się [Jopek 2015, s. 152-152]. Wyludnieniu niekiedy podlegają całe dzielnice miasta, co zdecydowanie obniża jego atrakcyjność. Jednocześnie na obrzeżach miast trwa proces „rozlewania” (niekontrolowane rozrastanie się obszarów zabudowanych).

Kurczenie się miast w Polsce jest zjawiskiem zróżnicowanym i złożonym ze względu na przyczyny, konsekwencje i kontekst przestrzenny. Nie ma jednego modelu kurczenia się miast. W wielu ośrodkach miejskich występuje więcej niż jedna przyczyna ubytku mieszkańców.

\section{Demograficzne aspekty kurczenia się miast w Polsce}

Miejska sieć osadnicza w Polsce ulega ciągłym przemianom o różnej dynamice i zakresie. W 2015 roku sieć osadniczą kraju tworzyło 915 miast o różnej wielkości. W ciągu 15 lat liczba miast w Polsce zwiększyła się - o 33 miasta w stosunku do 2000 roku. Pomimo wzrostu liczby ośrodków miejskich odnotowano spadek ludności miejskiej z 23877 tys. osób w 2000 roku do 23166 tys. w 2015 roku. Należy zaznaczyć, że liczba ludności w Polsce w badanym okresie nieznacznie wzrosła (o $0,5 \%$ ), podobnie na obszarach wiejskich (o 687 tys. osób, tj. o blisko 5\%), z kolei liczba ludności w miastach spadła o ponad 2\% (rys. 2).

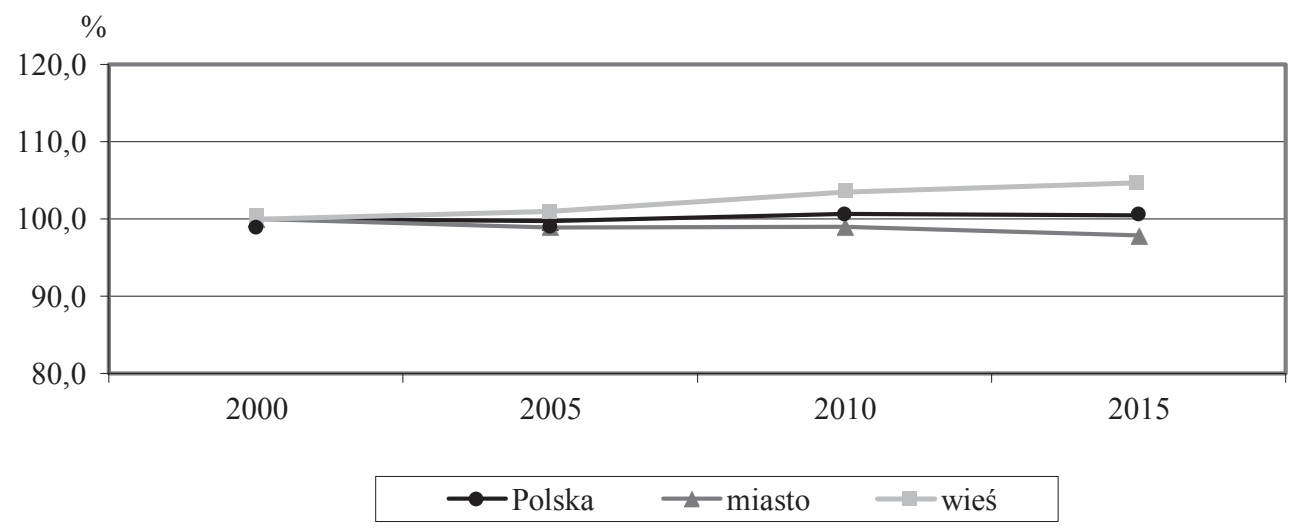

Rys. 2. Zmiana liczby ludności miejskiej w Polsce według klas wielkościowych miast (2000=100\%) Źródło: opracowanie własne.

Do najważniejszych przyczyn wpływających na obecny stan demograficzny Polski należą migracja ludności oraz spadek dzietności. Migracje wewnętrzne powodują przemieszczanie się ludności na terenie kraju pomiędzy miastem a wsią. Nie wpływają one na ubytek ludności, wzrasta jedynie liczba ludności na wsi, natomiast maleje w miastach. Odpływ ludności za granicę powoduje zmniejszenie się ludności miast i wsi. Należy zaznaczyć, że odpływ ludności w wyniku procesu suburbaniza- 
cji ma miejsce w dużych i średnich miastach, natomiast w przypadku mniejszych ośrodków miejskich - z przemieszczeniami do większych miast bądź migracjami zagranicznymi [Harańczyk 2015, s. 46].

Zachodzące procesy w sieci osadniczej w Polsce charakteryzowały się różną intensywnością. Ponad 1/3 miast Polski to miasta małe, liczące poniżej 5 tys. mieszkańców. W 2015 roku stanowiły one 36\% wszystkich miast i skupiały łącznie 4,3\% ogółu ludności miejskiej. W latach 2000-2015 widoczny jest znaczny wzrost liczby miast najmniejszych, natomiast udział ludności tych miast w ogólnej liczbie ludności miejskiej zwiększył się zaledwie o 0,6 pkt. proc. W 2015 roku zbiór miast liczących od 5 do 10 tys. mieszkańców obejmował 178 miejscowości. Miasta te stanowiły $19,5 \%$ liczby wszystkich miast kraju. W analizowanym okresie w tej grupie miast miał miejsce nieznaczny spadek liczby miast (o 3 miasta mniej niż w roku wyjściowym 2000) oraz liczby ludności miejskiej (o 26,4 tys. osób). Korzystniejsza sytuacja wystąpiła w miastach liczących od 10 do 20 tys. mieszkańców - ich liczba wzrosła o 6. Wzrosła również liczba ich mieszkańców o 49 tys. oraz nieznacznie zwiększył się udział ludności miejskiej tych miast w ogólnej liczbie ludności (z 11,2\% w 2000 do 11,8\% w 2015 r.). System osadniczy Polski na koniec 2015 r. stanowiły 133 miasta średniej wielkości, tj. liczące od 20 do 50 tys. mieszkańców. Koncentrowały one ok. 15,0\% ogólnej liczby miast polskich. W latach 2000-2015 w tej grupie wielkościowej miast ich liczba wzrosła o 4 . W miastach tych zauważa się spadek liczby mieszkańców z 4222 tys. do 4162 tys. osób. Wzrósł jednak udział ludności tej grupy miast w ogólnej liczbie ludności miejskiej (z 17,7\% do 18,0\%). W badanym okresie nastąpiła nieznaczna zmiana liczby miast w przedziale od 50-100 tys. mieszkańców (mniej o 2 miasta), spadła również liczba ludności je zamieszkująca - z 3359 do 3199. W Polsce tylko 23 miasta liczyły od 100 do 200 tys. mieszkańców. W latach 2000-2015 ich liczba nie uległa zmianie, zauważa się jednak niewielki wzrost liczby mieszkańców tych miast. Należy zaznaczyć, że udział ludności tej grupy wielkościowej miast w poziomie koncentracji ludności miejskiej kraju prawie się nie zmienił - wzrósł o 1 pkt. proc. (rys. 3). W miastach największych, liczących powyżej 200 tys. mieszkańców, szczególnie zaznacza się osłabienie dynamiki demograficznej. W odniesieniu do tej grupy wielkościowej miast widoczny jest zarówno spadek liczby miast, jak i ludności miejskiej. Miasta te charakteryzowały się także spadkiem poziomu koncentracji ludności miejskiej z 35,2\% do 33,0\%.

W wielu miastach w Polsce widoczne są pierwsze symptomy depopulacji. Obecnie w miastach żyje 23,2 mln mieszkańców, na wsi zaś ok. 15,2 mln. W 2050 roku w miastach będzie 18,8 mln mieszkańców, a na wsi ponad 15,1 mln. Równocześnie z procesem wyludniania występują zmiany struktury ludności według ekonomicznych grup wieku. Ubytki ludności korespondują w dużej mierze ze wzrastającą liczbą osób starszych. Należy więc wspomnieć o zauważalnym w całym kraju nasilającym się procesie starzenia się społeczeństwa. Proces ten jest zróżnicowany przestrzennie, jego stopień zaawansowania zaś zależy od fazy rozwoju społeczeństwa. Z danych GUS-u wynika, że w końcu 2015 r. w Polsce ludność w wieku poprodukcyjnym stanowiła 19,6\% społeczeństwa. W badanym okresie również w ośrodkach 


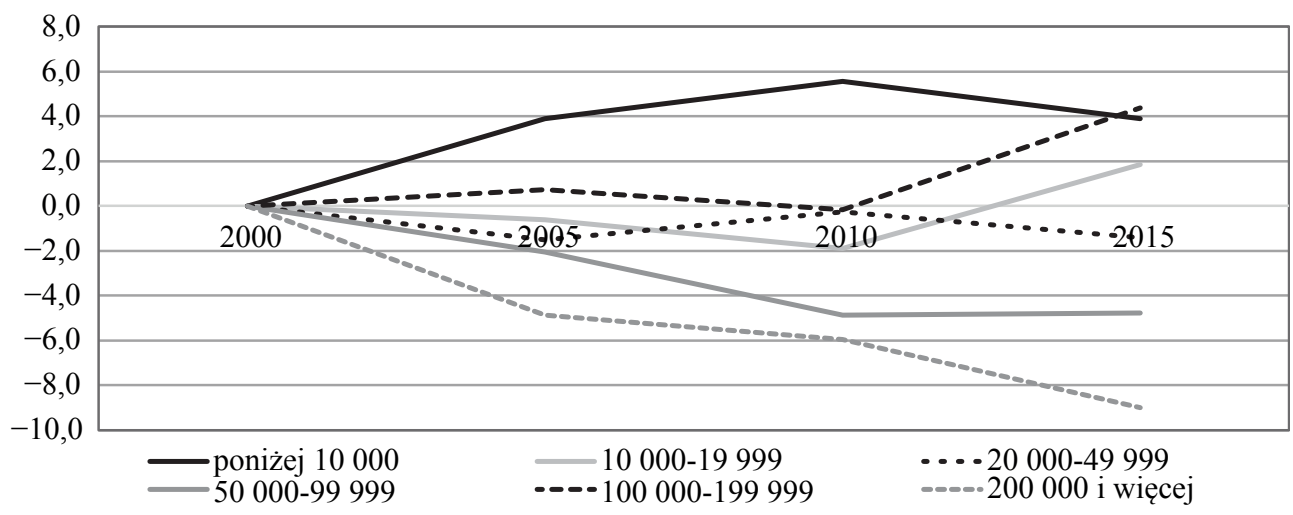

Rys. 3. Zmiana liczby ludności miejskiej w Polsce według klas wielkościowych miast (2000=100\%) Źródło: opracowanie własne.

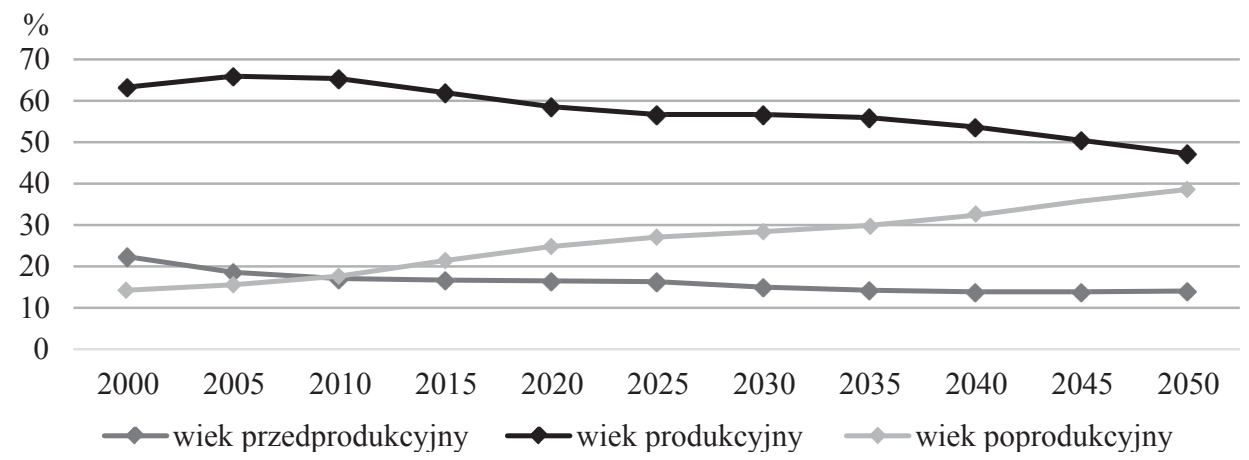

Rys. 4. Zmiany liczby ludności według wieku w miastach w Polsce w \% - stan i prognoza Źródło: opracowanie własne.

miejskich widoczny jest wzrost odsetka najstarszych mieszkańców miast (rys. 4). W stosunku do $2000 \mathrm{r}$. liczba osób w wieku poprodukcyjnym wzrosła prawie o 1/3. Z kolei populacja $w$ wieku przedprodukcyjnym w Polsce zmniejszyła się o ok. 26\%, w tym w miastach o $27 \%$. W analizowanym okresie wzrósł więc współczynnik obciążenia ekonomicznego, czyli iloraz liczby osób w wieku nieprodukcyjnym do liczby osób w wieku produkcyjnym, z 58 na 61. Proces starzenia się demograficznego miast będzie postępował, na co wskazuje prognoza GUS-u do 2050 roku. W miastach udział ludności powyżej 65 roku życia osiągnie w 2050 r. ponad $30 \%$ ogółu ich mieszkańców, a na 100 osób w wieku poprodukcyjnym będą przypadać 83 osoby.

Jak już wspomniano, podstawowymi składowymi zmian zaludnienia są przyrost naturalny i migracje. Na liczbę migracji miejskiej znaczący wpływ mają migracje wewnętrzne ludności odbywane między miastami i wsiami. Przez długi okres 
obszary miejskie charakteryzowały się napływem ludności, od roku 2000 obserwuje się tendencję odwrotną. Obecnie zjawisko to widoczne jest szczególnie w dużych miastach, zachodzą bowiem w nich procesy dekoncentracji ludności będące wynikiem procesu suburbanizacji.

W 2015 roku współczynnik przyrostu naturalnego ludności w miastach był ujemny przede wszystkim w wyniku mniejszej liczby urodzeń, przy jednoczesnym wzroście liczby zgonów. W latach 2000-2015 liczba urodzeń żywych w przeliczeniu na 1000 mieszkańców zwiększyła się, wzrosła jednocześnie liczba zgonów (odpowiednio: liczba urodzeń z 8,9 do 9,4/1000 ludności; liczba zgonów z 9,3 do 10,4/1000 ludności).

\section{Przemiany demograficzne w miastach wojewódzkich}

Badana grupa ośrodków obejmuje 18 miast liczących ogółem w 2015 r. 7 686,2 tys. osób, tj. 20\% populacji całego kraju. Można w niej wydzielić:

- 5 miast powyżej 500 tys. mieszkańców (Warszawa, Kraków, Łódź, Wrocław, Poznań);

- 5 miast pomiędzy 300 a 500 tys. mieszkańców (Gdańsk, Szczecin, Bydgoszcz, Lublin),

- 6 miast pomiędzy 200 a 300 tys. mieszkańców (Białystok, Katowice, Toruń),

- 6 miast z liczbą ludności z przedziału 100-200 tys. (Rzeszów, Kielce, Gorzów Wielkopolski, Zielona Góra, Opole, Olsztyn).

Poddając analizie lata 2000-2015, można zauważyć, iż w większości miast wojewódzkich widoczny jest spadek liczby ludności. Najwięcej straciła Łódź 97,4 tys. mieszkańców i Katowice - 30,7 tys. mieszkańców. Na kolejnych pozycjach znalazły się miasta: Opole, Kielce, Poznań, Bydgoszcz i Lublin. W pozostałych miastach spadek wielkości populacji nie przekraczał 3,6\% ogólnej liczby ludności. Miasta charakteryzujące się obecnie największym ubytkiem ludności w minionym okresie były typowymi ośrodkami przemysłowymi o historycznie wykształconej monokulturze. Gospodarka tych miast oparta była na wielkich przedsiębiorstwach specjalizujących się w wydobyciu węgla, hutnictwie, chemii przemysłowej i włókiennictwie [Szukalski 2014, s. 2]. Ograniczenie zatrudnienia w przemyśle stało się ważną przesłanką depopulacji tych miast. Ubytek mieszkańców występuje również w miastach dotkniętych procesem suburbanizacji. Jedynie w sześciu miastach odnotowano wzrost liczby mieszkańców, przy czym największy wystąpił w Zielonej Górze i Rzeszowie - powyżej 15\%. Do pozostałych miast o tendencjach wzrostowych należały: Warszawa (wzrost o 4,3\%), Białystok (2,3\%), Kraków i Olsztyn (po $0,3 \%$ ).

Jak wspomniano, w ostatnich latach obserwuje się wzrost odsetka osób powyżej 60 roku życia. Pomimo różnic między poszczególnymi miastami wojewódzkimi widoczna jest wyraźna tendencja wzrostu odsetka osób starszych, czemu towarzyszyć będzie obniżanie się udziału dzieci i młodzieży. Analiza prowadzi do wniosku, iż 
spośród 18 ośrodków Łódź jest miastem, które w badanym okresie charakteryzowało się najwyższym odsetkiem ludności w wieku poprodukcyjnym (ponad 25\% w 2015 r.). Równie wysoki wskaźnik osiągnęły Katowice (powyżej 23\%). Z kolei najwyższymi wskaźnikami w grupie dzieci i młodzieży wyróżniały się miasta: Rzeszów i Gorzów Wielkopolski (wskaźniki dla obydwu miast kształtowały się na poziomie powyżej 17\%) (rys. 5, 6).

Dotychczasowe tendencje przemian w poziomie dynamiki zaludnienia i przeobrażeń struktury wieku będą wpływać na perspektywiczne charakterystyki demograficzno-społeczne badanych miast. Tendencje zmian demograficznych będą się kształtować różnie w poszczególnych miastach wojewódzkich. W większości ośrodków miejskich do roku 2050 zarysuje się trend depopulacji, tylko w dwóch miastach nastąpi wzrost liczby ludności (w Warszawie i Rzeszowie).

Prognozy demografów pokazują, że do 2050 r. mieszkańcy wszystkich stolic regionów polskich będą się gwałtownie starzeć. Będzie to mieć związek z ujemnym przyrostem naturalnym i niską dzietnością kobiet. W prognozowanym okresie przewidywany jest spadek liczby ludności w grupach w wieku przedprodukcyjnym. Zmiany na skutek migracji ludności wystąpią również w wieku produkcyjnym i poprodukcyjnym.

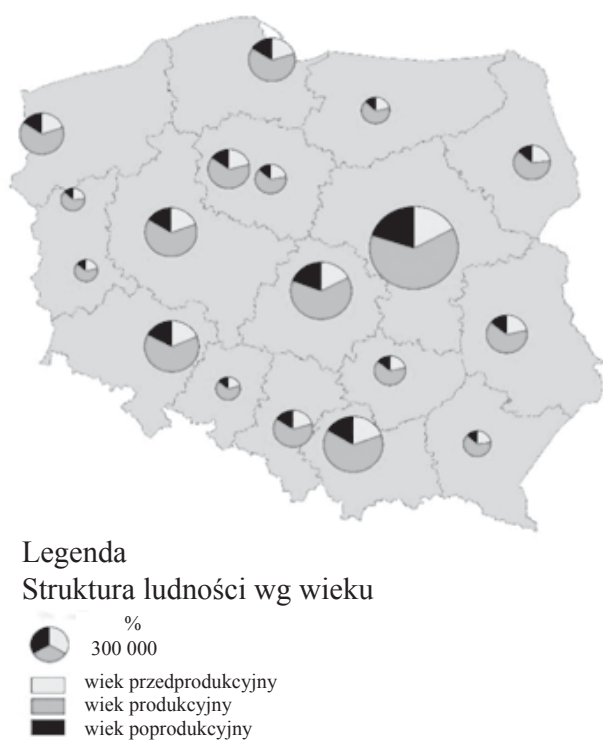

Rys. 5. Struktura ludności według wieku w miastach wojewódzkich w $2000 \mathrm{r}$.

Źródło: opracowanie własne.

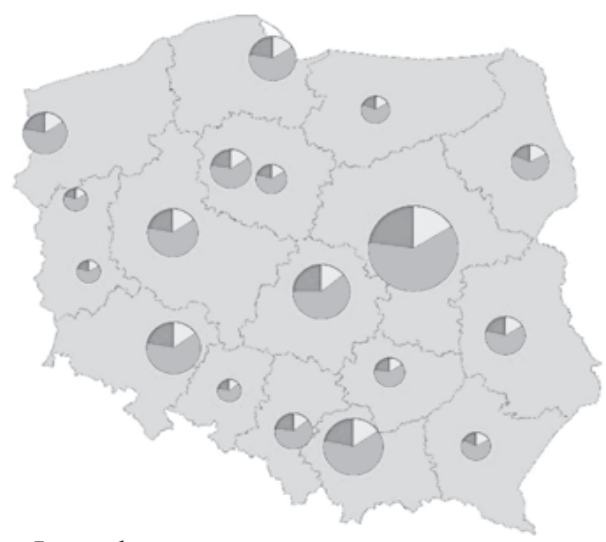

Legenda

Struktura ludności wg wieku

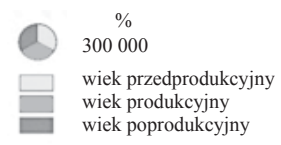

Rys. 6. Struktura ludności według wieku w miastach wojewódzkich w $2015 \mathrm{r}$.

Źródło: opracowanie własne. 


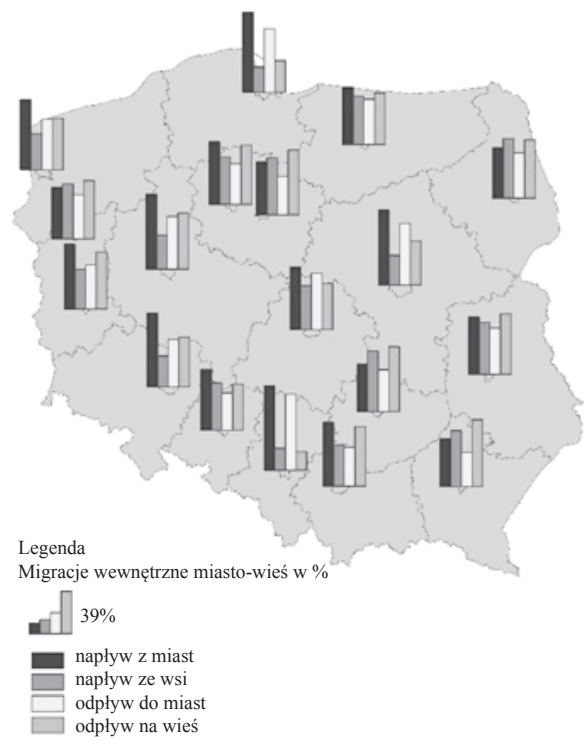

Rys. 7. Migracje miasto-wieś w miastach wojewódzkich w $2000 \mathrm{r}$.

Źródło: opracowanie własne.

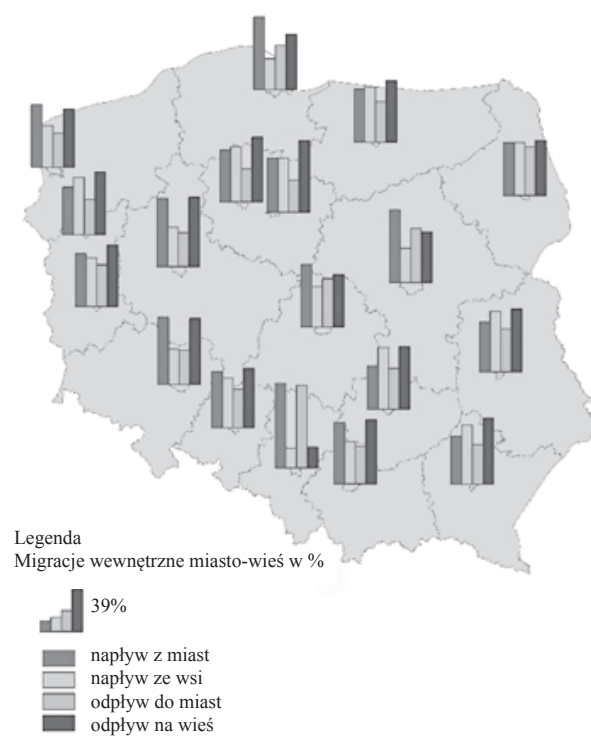

Rys. 8. Migracje miasto-wieś w miastach wojewódzkich w 2015 r.

Źródło: opracowanie własne.

Zmiany pod względem przyrostu naturalnego ludności różnią się nieco swoim przebiegiem w omawianych miastach wojewódzkich. W poddanych analizie jednostkach odnotowano ujemny ubytek naturalny w 9 miastach. Najwyższe wartości wskaźników są charakterystyczne dla dwóch stolic województw, tj. Łodzi i Katowic, odpowiednio $-6,3$ i $-3,4$ osoby/1000 ludności. W pozostałych 9 miastach współczynnik przyrostu naturalnego ludności przyjmował wartości dodatnie. W grupie tej wyróżniały się przede wszystkim Rzeszów i Białystok, gdzie w 2015 r. wskaźniki te osiągnęły odpowiednio 2,2 i 1,8 osób w przeliczeniu na 1000 mieszkańców.

W przyjętym do badania interwale czasowym migracje w miastach wojewódzkich wykazywały wewnętrzne zróżnicowanie (rys. 7, 8). Odpływ ludności z miast był większy niż napływ do obszarów miejskich. Duże wartości współczynnika odpływu ludności z miast w 2015 r. zaobserwowano w Poznaniu, Łodzi, Bydgoszczy i Katowicach. Maksymalne wartości napływu ludności do miast miały miejsce w Warszawie, Krakowie i Wrocławiu.

Spadek odpływu ludności notowany w przyjętym przekroju czasowym wystąpił w Rzeszowie i Gdańsku. Saldo migracji w przeliczeniu na 1000 mieszkańców było najwyższe w Warszawie. Wartości dodatnie salda migracji odnotowano również w Zielonej Górze, Wrocławiu, Rzeszowie, Krakowie, Gdańsku, Olsztynie i Białymstoku. Pozostałe jednostki odnotowały saldo ujemne, przy czym największe wystąpiło w Poznaniu, Katowicach i Bydgoszczy (powyżej 3 osób na 1000 
mieszkańców). Na podstawie przeprowadzonych analiz można stwierdzić, że dominują przemieszczenia w kierunku obszarów metropolitalnych, zachodzą jednocześnie procesy dekoncentracji ludności wewnątrz tych obszarów będące wynikiem napływu mieszkańców na obszary podmiejskie. Ponadto widoczny jest odpływ ludności z byłych ośrodków przemysłowych [Stryjakiewicz 2014, s. 69].

\section{Podsumowanie}

Analiza sytuacji miast wojewódzkich w badanym interwale czasowym pozwala stwierdzić, że następuje proces kurczenia się miast, który w przyszłości będzie nadal postępował. Badany przedział czasowy charakteryzuje się spadkiem ludności na obszarach miejskich. Wraz ze spadkiem potencjału ludnościowego zachodzą niekorzystne zmiany w strukturze wiekowej mieszkańców miast. Jak pokazują aktualne prognozy demograficzne GUS-u, do 2050 r. nastąpi spadek liczby ludności miast, spadek liczby ludzi młodych i osób w wieku zdolności do pracy oraz starzenie się populacji. Skutki tego procesu w większości przypadków będą negatywne. Szczególnie trudna sytuacja występuje w ośrodkach miejskich, gdzie spadek liczby mieszkańców powoduje niekorzystne zjawiska w lokalnych strukturach społecznych, gospodarczych czy przestrzennych.

Proces kurczenia się miast stwarza nowe wyzwania stawiane polityce miejskiej oraz w zakresie planowania przestrzennego. Konieczne jest więc podjęcie przez władze administracyjne i samorządowe różnych szczebli skutecznych działań mających na celu zapobieganie negatywnym skutkom tego procesu.

\section{Literatura}

Bernt M., Cocks M., Couch C., Grossmann K., Haase A., Rink D., 2012, Policy Response, Governance and Future Directions, Shrink Smart Research Brief, no. 2, March, Helmholtz Centre for Environmental Research - UFZ, Leipzig.

Couch C., Cocks M., Bernt M., Grossmann K., Haase A., Rink D., 2012, Shrinking cities in Europe, Town \& Country Planning, June.

Czarnecki B., 2011, Przejawy i konsekwencje depopulacji polskich miast. Zarys problemu, Architecturae et Artibus, 4/2011, Politechnika Białostocka, Wydział Architektury, Białystok.

Haase A., 2013, No one-size-fits-all. O różnorodności kurczących się miast w Europie, [w:] Zarządzanie rozwojem miast o zmniejszającej się liczbie mieszkańców (w kontekście perspektywy finansowej 2014-2020), Kancelaria Senatu, Warszawa.

Haase A., Bernt M., Grossmann K., Mykhnenko V., Rink D., 2013, Varieties of shrinkage in European cities, European Urban and Regional Studies, http://www.policy.hu/mykhnenko/Haase\%26others 2013EURs.pdf.

Harańczyk A. (red.), 2015, Uwarunkowania i konsekwencje procesu kurczenia się miast w Polsce, CeDeWu Sp z o.o., Warszawa. 
Jaroszewska E., 2013, Akcja CiRES „Cities Regrowing Smaller” organizowana przez COST (European Cooperation in Science and Technology), [w:] Zarzadzanie rozwojem miast o zmniejszajacej się liczbie mieszkańców (w kontekście perspektywy finansowej 2014-2020), Kancelaria Senatu, Warszawa.

Jopek D., 2015, Przestrzenne aspekty procesu kurczenia się miast, [w:] Harańczyk A. (red.), Uwarunkowania i konsekwencje procesu kurczenia się miast w Polsce, CeDeWu Sp. z o.o., Warszawa.

Kantor-Pietraga I., Krzysztofik R., Runge J., 2012, Kontekst geograficzny i funkcjonalny kurczenia sie matych miast w Polsce południowej, [w:] Heffner K., Halama A. (red.), Ewolucja funkcji małych miast w Polsce, Uniwersytet Ekonomiczny w Katowicach, Katowice.

Kantor-Pietraga I., 2014, Systematyka procesu depopulacji miast na obszarze Polski od XIX do XXI wieku, Uniwersytet Śląski, Katowice.

Musiał-Malago' M., 2015, Przemiany gospodarcze w miastach Polski, [w:] Harańczyk A. (red.), Uwarunkowania i konsekwencje procesu kurczenia się miast w Polsce, CeDeWu Sp. z o.o., Warszawa.

Rink D., Haase A., Grossmann K., Couch C., Cocks M., 2012, From long-term shrinkage to re-growth? A comparative study of urban development trajectories of Liverpool and Leipzig, Built Environment, 38.

Stryjakiewicz T., 2014, Kurczenie się miast w Europie Środkowo-Wschodniej, Bogucki Wydawnictwo Naukowe, Poznań.

Szukalski P., 2013, Sytuacja demograficzna Łodzi. Porównanie z innymi wielkimi polskimi miastami, [w:] Zarządzanie rozwojem miast o zmniejszajacej się liczbie mieszkańców (w kontekście perspektywy finansowej 2014- 2020), Kancelaria Senatu, Warszawa. 